\title{
Habit and hedonic motivation are the strongest influences in mobile learning behaviours among higher education students in Malaysia
}

\author{
Krishna Moorthy, Tsen Tzu Yee, Loh Chun T'ing, Vikniswari Vija Kumaran \\ Universiti Tunku Abdul Rahman
}

\begin{abstract}
Mobile learning has become a common experience in higher education and in the professional workforce. However, the readiness of accounting students to engage in such learning appears to be weaker than in other disciplines. Therefore, this study set out to identify the factors affecting accounting students' behavioural intention (BI) to accept mobile learning. The participants of this study were 358 accounting students of public universities in Malaysia. The study was anchored in the unified theory of acceptance and use of technology 2 (UTAUT2) (Venkatesh, Thong \& Xu, 2012), which has been employed by researchers in various research areas such as mobile payments, e-learning, mobile banking, and online shopping. The study revealed that habits have the most influence on accounting students' intention to adopt mobile learning through an investigation of technology acceptance in the domain of mobile learning. From the perspective of universities, the study posits that consistent usage of mobile learning could be encouraged through processes to nurture students' habits when using mobile learning system as a tool to complete tasks. Findings provide a reference for the future UTAUT2 and mobile learning related studies.
\end{abstract}

\section{Introduction}

Development in mobile technology has been rapid over the past decade. According to a report of International Telecommunication Unit, worldwide there were more than 7,000 million users with a mobile line at the end of 2016 (International Telecommunication Unit, 2016). The advancement of mobile technology has altered the role of accounting professionals in a number of ways. It has increased the number of the tools available to accountants and gradually changed their approach to access and deliver data. The decision-making process has also improved due to the enhancement quality and timeliness of reports (Amirul, Mail, Bakar, \& Ripain, 2017). In light of the shifts in technoloy, it is imperative for accounting graduates to equip themselves with a wider range of technical skills as compared to the past. This bolsters the need for the accounting curriculum to harness digital technologies which are instrumental to exposing students to the technology-rich world (Watty, McKay, \& Ngo, 2016).

The integration of mobile technology into higher education has gained considerable attention (Almaiah, Jalil, \& Man, 2016). Mobile devices, especially smart phones, are the most frequently used technological devices for daily routines. Reflecting this, they are being integrated into teaching (Yurdagül \& Öz, 2018). Kengwe and Bhargava (2014) define mobile learning (mobile learning) as a dynamic learning environment using wireless mobile devices such as mobile phones, personal digital assistants (PDAs), iPads, and smart phones. Mobile learning allows students to access course materials as well as learning activities at any location and in real time (Abachi \& Muhammad, 2014), and to share ideas with others, and participate actively in a collaborative environment (Nassuora, 2012), thus overcoming the deficiencies of e-learning such as lack of human interaction and enthusiasm (Sabah, 2016).

According to the Ambient Insight Comprehensive Report (2015), in Asia, Malaysia is ranked fifth highest for predicted mobile learning growth rates for 2014 to 2019. In spite of this mobile learning in Malaysia is still in an emerging stage (Ismail, Gunasagaran, \& Azizan, 2016). Most projects or studies continue to emphasise the notion of establishing foundation, theory, forms of mobile learning, and activities sustained by mobile technology (Hussin, Manap, Amir, \& Krish, 2012; Pollara \& Kee, 2011).

In recent years, employers have expressed dissatisfaction with the technological skills demonstrated by accounting graduates (El-Dalahmeh, 2017), despite their satisfactory functional competencies (Sithole, 2015). The integration of technology into accounting education has not kept pace with the working environment (Staples, Collum, \& McFry, 2016), creating a gap in technical proficiency between students and professionals. Accounting students must be equipped with solid fundamentals to grasp accounting- 
related technical skills (Amirul et al., 2017; Cory \& Peruske, 2012) in order to meet the requirements of different stakeholders (El-Dalahmeh, 2017).

\section{Problem statement}

Given the extensive utilisation of mobile devices by accounting professionals for accessing and sharing data, incorporating mobile devices into the classroom appears to be a solution to improve accounting graduates' technical expertise (Staples et al., 2016). In order to engage the digital generation in the learning process, interactive learning such as mobile learning is recommended in the higher education classroom (Lewis, Fretwell, Ryan, \& Parham, 2013; Watty et al., 2016). However, the success or failure of mobile learning implementation depends on learners' readiness to embrace technology for their education (Ismail et al., 2016). To enable mobile learning to be a field of research, it requires the theories, methodologies, and practices of its own (Aguayo, Cochrane, \& Narayan, 2017). To enrich the studies on mobile learning field, the objective of this study is to identify the factors affecting accounting students' BI to accept mobile learning.

\section{Theoretical model}

Users' acceptance and adoption of technology has captured the attention of various scholars and become a principal field of study over the past few decades (Sabah, 2016). The need to explain the usage behaviour of technologies and their determinants has prompted the development of a number of theoretical frameworks (Jackman, 2014). These include the theory of reasoned action (TRA) (Fishbein \& Ajzen, 1975), the theory of planned behaviour (TPB) (Ajzen, 1985), the technology acceptance model (TAM) (Davis, 1986), and the diffusion of innovation model (DOI) (Rogers, 1995). Nevertheless, most of these frameworks possessed inadequate predictive capabilities and were constructed on insufficient empirical evidence (Ooi \& Tan, 2016; Tan, Lee, Lin, \& Oois, 2017). In 2003 Venkatesh, Morris, Davis, and Davis proposed the unified theory of acceptance and use of technology (UTAUT). UTAUT2 was later proposed by Venkatesh et al. (2012) as a model to comprehend consumer behaviour when using technologies. UTAUT2 comprises seven independent variables, incorporated price value (PV), hedonic motivation (HM), and habit (HT), with the existing variables of performance expectancy (PE), effort expectancy (EE), social influence (SI), facilitating conditions (FC). Behavioural intention (BI) is the mediating variable, while use behaviour plays the role of the dependent variable. In addition, age, gender, and experience are included as moderators. Nevertheless, this paper excludes use behaviour in the framework since mobile learning is still at its infancy stage of development in Malaysia. Instead of investigating the present use of mobile learning technology, this research explores the future acceptance of such advancement (Tan et al., 2017). Moreover, actual adoption is hard to gauge (Zhu, Wei, \& Zhao, 2016).

Extensions of the model from UTAUT to UTAUT2 yielded significant information to explain the discrepancy described in BI and technology use (TU) (Mtebe, Mbwilo, \& Kissaka, 2016). UTAUT2 has been employed by researchers in various research areas such as consumers' intention to use mobile payments (Morosan \& DeFranco, 2016), e-learning system adoption (El-Masri \& Tarhini, 2017), mobile banking adoption (Alalwan, Dwivedi, \& Rana, 2017) and online shopping adoption (Tandon, Kiran, \& Sah, 2016). This research has adopted the UTAUT2 model because of its superiority over existing frameworks.

In addition, the moderators of UTAUT2, namely age and experience, have not been included in the study. Due to the preliminary development of mobile learning and improper incorporation of such technology into the university courses to date, there is a lack of convincing argument to integrate the user experience with mobile learning (Jackman, 2014). Past researchers have also excluded experience as a moderator because its moderating effect on BI is insignificant (Kimball, 2015; Rahman, Jamaludin, \& Mahmud, 2011). Moreover, age was disregarded as a moderator since the target population of this research was undergraduates in a narrow range of ages (Wong, Tan, Loke, \& Ooi, 2014). Nevertheless, this study retained gender as a moderator. Prior literature pertaining to mobile education in Malaysia, found the moderating effect of gender to be inconclusive (Tan et al., 2017; Leong, Ooi, Chong, \& Lin, 2013; Tan, Ooi, Chong, \& Hew, 2014), hence, this study sought to probe the effect of gender on the association between the independent constructs and BI. 


\section{Literature review}

\section{Behavioural intention}

BI indicates a person's readiness to use a particular technology for various tasks (Ain, Kaur, \& Waheed, 2015). It evaluates the strength of a user's commitment to perform a specific behaviour and shows the intensity of an individual's intention to adopt a specific behaviour (Davis, 1986). Fishbein and Ajzen (1975) posited that BI is reflected as a signal of actual behaviour and predicts actual usage (Chang, 2016).

This construct has been widely used as an antecedent of user acceptance in various technology acceptance theories (Almaiah et al., 2016). Extant studies such as mobile learning (Briz-Ponce, Pereira, Carvalho, Juanes-Mendez, \& Garcia-Penalvo, 2017), virtual reality in learning (Shen, Ho, Kuo, \& Luong, 2017), elearning (Chang, Hajiyev, \& Su, 2017), and social networking sites (Chuang, Lin, Chang, \& Kaewmeesri, 2017) integrated BI to evaluate adoption and implementation of technology. Thus, BI is regarded as the prime determinant in this current research.

\section{Performance expectancy}

The extent of advantages delivered to individuals in completing tasks through the adoption of a particular technology is denoted by PE (Arenas-Gaitan, Peral-Peral, \& Ramon-Jeronimo, 2015). In the context of mobile learning, students may believe that the learning system is beneficial as it enhances their work performance and learning productivity (Abu-Al-Aish \& Love, 2013), apart from allowing them to acquire knowledge conveniently and rapidly (Jackman, 2014). Lawrence (2016), Arenas-Gaitan et al. (2015), and Jackman (2014) all emphasised that BI was significantly affected by PE. Thus, the following hypothesis is proposed:

H1. The association between PE and BI is significant enough to warrant utilisation of mobile learning among Malaysia’s accounting students in public universities.

\section{Effort expectancy}

EE refers to the level of ease associated with an individual's adoption of technology (Arenas-Gaitan et al., 2015). In this context, EE is the degree to which a learner perceives that using mobile learning services and its relevant features will be free from effort (Al-Hujran, Al-Lozi, \& Al-Debei, 2014). Prior studies by Magsamen-Conrad, Upadhyaya, Joa, and Dowd (2015), De Sena Abrahao, Moriguchi, and Andrade (2016), and Chauhan and Jaiswal (2016) posited that BI was strongly influenced by EE. Therefore, the following hypothesis is suggested:

$\mathrm{H} 2$. There is a significant enough relationship between effort expectancy (EE) and BI (BI) to adopt mobile learning among Malaysia's accounting students in public universities.

\section{Social influence}

SI is the degree to which students recognise that significant parties, such as peers, lecturers, and family members, perceive they should embrace mobile learning system (Al-Hujran et al., 2014). This factor is deemed to be prominent in the primary stage of technology acceptance (Jackman, 2014). Ahmad and Khalid (2017), Lakhal and Khechine (2016), and Sabah (2016) confirmed that SI posed significant effect on BI. Thus, the study proposes to test the following hypothesis:

H3. SI possesses a significant enough effect on BI to indicate the value of embracing mobile learning among Malaysia’s accounting students in public universities.

\section{Facilitating conditions}

FC denote the students' insights into the availability of organisational resources and technical support affecting the adoption of a mobile learning system (Al-Hujran et al., 2014). This factor also gauges the students' confidence of their possession of knowledge essential to the utilisation of mobile learning (Jackman, 2014). Kurfali, Arifoğlu, Tokdemir, and Paçin (2017), Bakar and Razak (2014), and 
Magsamen-Conrad et al. (2015) postulated that BI is predicted by FC. Hence, the following hypothesis is formulated:

H4. FC have a significant impact on the BIs of accounting students in Malaysian public universities acceptance of mobile learning.

\section{Hedonic motivation}

According to Venkatesh et al. Xu (2012), HM can be described as the pleasure derived from the adoption of a technology. It reflects a learner's impression of smartphones as engaging and pleasing for educational purpose (Ahmed, 2016). In line with motivation theory, HM is pivotal in influencing technology adoption among users (Yang, 2013). Some investigations had validated HM's positive linkage with BI (Alalwan et al., 2017; Herrero \& San Martin, 2017; Kang, Liew, Lim, Jang, \& Lee, 2015). Therefore, the following hypothesis is formed:

H5. HM has a significant enough relationship with BI to warrant the utilisation of mobile learning among Malaysia's accounting students in public universities.

\section{Price Value}

Venkatesh et al. (2012) explained PV as the individuals' insights regarding the trade-off between perceived benefits received and monetary cost paid for adopting the technology. In contrast with the organisational use setting, individual consumers generally endure the monetary cost of using a technology (Yang, 2013). The findings of Nair, Ali, and Leong (2015), Sung and Sung (2015), and Xu (2014) showed that BI is significantly influenced by PV. This leads to the next hypothesis:

H6. PV has significant connections with the BIs of Malaysian accounting students in public universities, in their adoption of mobile learning.

\section{Habit}

Venkatesh et al. (2012) posited that HT refers to an individuals' degree of inclination to execute behaviours automatically in the learning process. In the context of mobile learning, if a student has a higher level of automaticity to use the mobile phone, the learner will possess higher intention to utilise mobile learning than students with a lower level of automaticity (Yang, 2013). Past studies conducted by Harsono and Suryana (2014), Escobar-Rodriguez, Carvajal-Trujillo, and Monge-Lozano (2014), and Yeh and Tseng (2017), concluded that HT exerts positive influence on BI. Thus, the following hypothesis is proposed:

H7. There is a significant linkage between HT and BI supporting mobile learning among Malaysia's accounting students in public universities.

\section{Gender}

In the studies of Goh and Sun (2014) and Liu and Guo (2017), the researchers found that men and women possess diverse perceptions regarding information technologies such as mobile phones and computers. Men in their study were more inclined to explore innovations as they are active, adventurous (Zhang, Guo, Lai, Guo, \& Li, 2013), and risk taking (Garbarino \& Strahilevitz, 2004). On the other hand, women in their study were passive (Zhang et al., 2013) and anxious about computers and mobile technology (Gilbert, Lee-Kelley, \& Barton, 2003; Liu \& Guo, 2017).

Ahmed (2016) found in his study that men were more influenced by PE whereas effort expectancy affected women more significantly than men. Men in their study were more pragmatic and task-oriented than women (Zhou, Jin, \& Fang, 2014). Gender (GT) has also been found to moderate the effects of social influence (Faqih \& Jaradat, 2015; Venkatesh et al., 2012; Wang, Wu, \& Wang, 2009). Women in their study were more aware of others' viewpoints and inclined to interact with people before using new technology (Tan et al., 2017). Wong et al. (2014) supported that men in their study relied on FC to assist in the attainment of goals. 
Drawing from the research of Ahmed (2016), the influence of HM appeared weak among males. The women in his study were more engaged with and pleased to use smartphones academically. On the other hand, Indrawati and Marhaeni (2015) found that females were more concerned about PV when using instant messenger applications. Moreover, Venkatesh et al. (2012) postulated that GT moderated the effect of HT. It can be deduced that GT plays a crucial role as a moderator of the intention to implement a technology (Ahmed, 2016). This leads to the following hypotheses:

H8. The association between accounting students' BI towards utilising mobile learning in Malaysia's public universities and PE is significantly moderated by GT.

H9. The association between accounting students' BI towards utilising mobile learning in Malaysia's public universities and effort expectancy is significantly moderated by GT.

H10. The linkage between accounting students' BI towards utilising mobile learning in Malaysia's public universities and SI is significantly moderated by GT.

H11. The correlation between accounting students' BI towards utilising mobile learning in Malaysia's public universities and FC is significantly moderated by GT.

H12. The association between accounting students' BI towards utilising mobile learning in Malaysia's public universities and HM is significantly moderated by GT.

H13. The correlation between accounting students' BI towards utilising mobile learning in Malaysia's public universities and PV is significantly moderated by GT.

H14. The correlation between accounting students' BI towards utilising mobile learning in Malaysia's public universities and HT is significantly moderated by GT.

A research framework depicting the hypotheses has been developed as shown in Figure 1.

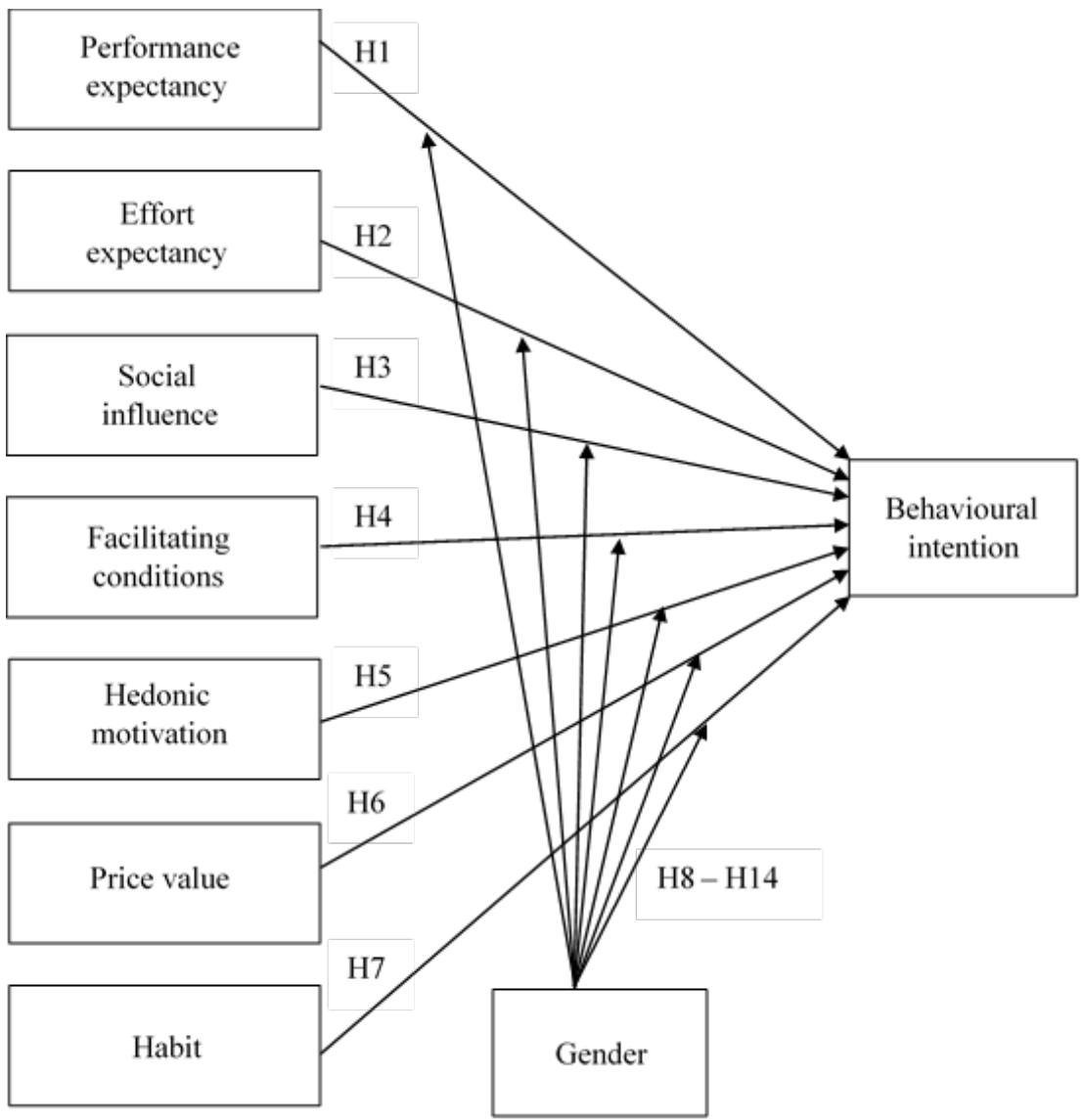

Figure 1. Research framework, adapted from Venkatesh et al. (2012) 


\section{Methodology}

Survey methodology was employed for this research and data were collected through structured questionnaires. The questionnaires were disseminated through the internet (Google Form), and also via personal delivery and collection. The target population of this study was accounting students in the public universities of Malaysia. Universiti Malaya (UM), Universiti Kebangsaan Malaysia (UKM), Universiti Teknologi MARA (UiTM), and Universiti Putra Malaysia (UPM) were the sampling locations. These four universities were chosen because they were the top four public universities in Malaysia according to the Quacquarelli Symonds University Rankings for Accountancy and Finance Subjects in 2017.

In accordance with Hinkin's (1995) sample size recommendations of an item-response ratio of between 1:4 and 1:10, for our questionnaire of 41 items a sample size of 164 to 400 respondents is considered as adequate. Therefore, 400 questionnaires were disseminated to the respondents. The questionnaire consisted of 41 items: 35 independent variable and 6 dependent variable items. The independent variables included PE, EE, SI, FC, HM, PV, and HT, while the dependent variable was BI. All variables were measured using a 5-point Likert scale, ranging from $1=$ strongly disagree to $5=$ strongly agree.

\section{Results}

\section{Descriptive analysis}

Respondent demographic profile

Of the 400 questionnaires, 358 valid responses were collected from respondents, achieving a response rate of $89.50 \%$. The data were analysed using the partial least squares structural equation modelling (PLSSEM) approach supported by SmartPLS 3.0. The descriptive statistics of the respondents are given in Table 1. 
Table 1

Sample demographics

\begin{tabular}{|c|c|c|}
\hline Items & Frequency & Percent $(\%)$ \\
\hline \multicolumn{3}{|l|}{ Gender } \\
\hline Male & 213 & 59.5 \\
\hline Female & 145 & 40.5 \\
\hline \multicolumn{3}{|l|}{ Age } \\
\hline Below 19 years old & 1 & 0.3 \\
\hline $20-23$ years old & 355 & 99.1 \\
\hline Above 23 years old & 2 & 0.6 \\
\hline \multicolumn{3}{|l|}{ Race } \\
\hline Malay & 224 & 62.6 \\
\hline Indian & 45 & 12.6 \\
\hline Chinese & 87 & 24.2 \\
\hline Others & 2 & 0.6 \\
\hline \multicolumn{3}{|l|}{ Year of study } \\
\hline Degree year 1 & 130 & 36.3 \\
\hline Degree year 2 & 181 & 50.6 \\
\hline Degree year 3 & 35 & 9.8 \\
\hline Degree year 4 & 12 & 3.3 \\
\hline \multicolumn{3}{|l|}{ University } \\
\hline Universiti Malaya & 71 & 19.8 \\
\hline Universiti Putra Malaysia & 113 & 31.6 \\
\hline Universiti Kebangsaan Malaysia & 101 & 28.2 \\
\hline Universiti Teknologi MARA & 73 & 20.4 \\
\hline \multicolumn{3}{|l|}{ Mobile device ownership } \\
\hline Yes & 358 & 100 \\
\hline No & 0 & 0 \\
\hline \multicolumn{3}{|l|}{ Internet accessibility of mobile devices } \\
\hline Yes & 356 & 99.4 \\
\hline No & 2 & 0.6 \\
\hline \multicolumn{3}{|l|}{ Experience of using mobile devices } \\
\hline Less than 1 year & 2 & 0.6 \\
\hline $1-3$ years & 9 & 2.5 \\
\hline $3-5$ years & 104 & 29.0 \\
\hline More than 5 years & 243 & 67.9 \\
\hline \multicolumn{3}{|c|}{ Frequency of using mobile devices for learning } \\
\hline Low ( 1 - 2 times per day) & 63 & 17.6 \\
\hline Moderate (3 - 4 times per day) & 123 & 34.3 \\
\hline High ( 5 - 7 times per day) & 137 & 38.3 \\
\hline None of the above & 35 & 9.8 \\
\hline
\end{tabular}

Reliability test

The reliability statistics are presented in Table 2. HT attained the highest value of 0.877 whereas facilitating conditions (FC) gained the lowest value of 0.813 . The reliability of all the variables were fulfilled as their Cronbach's alpha values exceeded 0.70 (Kline, 2015).

Table 2

Reliability test

\begin{tabular}{lrr}
\hline Variable & Number of items & Cronbach's alpha \\
\hline PE & 5 & 0.850 \\
EE & 5 & 0.871 \\
SI & 5 & 0.824 \\
FC & 5 & 0.813 \\
HM & 5 & 0.815 \\
PV & 5 & 0.858 \\
HT & 5 & 0.877 \\
BI & 6 & 0.833 \\
\hline
\end{tabular}




\section{Normality test}

The results of the normality test are furnished in Table 3. The range of skewness was between -0.464 and -1.122 , and the range of kurtosis was between -0.169 and 1.870 . Since all the skewness and kurtosis coefficients fell into the range of \pm 3 and \pm 10 respectively, all statistics were considered to have a normal distribution (Kline, 2015).

Table 3

Normality test

\begin{tabular}{|c|c|c|c|}
\hline Variables & Items & Skewness & Kurtosis \\
\hline \multirow[t]{5}{*}{$\mathrm{PE}$} & PE1 & -0.842 & 0.778 \\
\hline & PE2 & -0.969 & 1.479 \\
\hline & PE3 & -0.817 & 0.945 \\
\hline & PE4 & -0.664 & 0.723 \\
\hline & PE5 & -0.966 & 1.579 \\
\hline \multirow[t]{5}{*}{$\mathrm{EE}$} & EE1 & -0.756 & -0.169 \\
\hline & EE2 & -0.899 & 0.257 \\
\hline & EE3 & -0.819 & 0.168 \\
\hline & EE4 & -0.894 & 0.346 \\
\hline & EE5 & -0.713 & -0.121 \\
\hline \multirow[t]{5}{*}{ SI } & SI1 & -0.745 & 0.196 \\
\hline & SI2 & -0.700 & 0.033 \\
\hline & SI3 & -0.746 & 0.207 \\
\hline & SI4 & -0.715 & 0.243 \\
\hline & SI5 & -0.715 & 0.168 \\
\hline \multirow[t]{5}{*}{$\mathrm{FC}$} & $\mathrm{FC} 1$ & -1.122 & 1.824 \\
\hline & $\mathrm{FC} 2$ & -0.965 & 1.408 \\
\hline & FC3 & -0.844 & 1.179 \\
\hline & $\mathrm{FC} 4$ & -1.013 & 1.870 \\
\hline & FC5 & -0.745 & 1.038 \\
\hline \multirow[t]{5}{*}{$\mathrm{HM}$} & HM1 & -0.608 & 0.734 \\
\hline & HM2 & -0.564 & 0.635 \\
\hline & HM3 & -0.508 & 0.392 \\
\hline & HM4 & -0.511 & 0.292 \\
\hline & HM5 & -0.464 & -0.021 \\
\hline \multirow[t]{5}{*}{ PV } & PV1 & -0.499 & -0.067 \\
\hline & PV2 & -0.515 & -0.121 \\
\hline & PV3 & -0.715 & 0.104 \\
\hline & PV4 & -0.635 & 0.373 \\
\hline & PV5 & -0.521 & 0.116 \\
\hline \multirow[t]{5}{*}{ HT } & HT1 & -1.039 & 0.511 \\
\hline & HT2 & -0.734 & 0.076 \\
\hline & HT3 & -0.874 & -0.389 \\
\hline & HT4 & -0.814 & 0.446 \\
\hline & HT5 & -0.889 & 0.622 \\
\hline \multirow[t]{6}{*}{ BI } & BI1 & -0.878 & 0.817 \\
\hline & $\mathrm{BI} 2$ & -0.813 & 0.728 \\
\hline & $\mathrm{BI} 3$ & -0.818 & 0.705 \\
\hline & BI4 & -0.719 & 0.615 \\
\hline & BI5 & -0.837 & 1.017 \\
\hline & BI6 & -0.745 & 0.565 \\
\hline
\end{tabular}




\section{Inferential analyses}

Measurement model assessment

Internal consistency reliability, indicator reliability, convergent validity, and discriminant validity are used to gauge the model's reliability and validity (Rosli, 2015). The summary of the measurement model assessment is given in Table 4.

Table 4

Measurement model assessment summary

\begin{tabular}{|c|c|c|c|c|}
\hline Variable & Item & Item loading & Composite reliability & AVE \\
\hline \multirow[t]{5}{*}{$\mathrm{PE}$} & PE1 & 0.741 & & \\
\hline & PE2 & 0.802 & & \\
\hline & PE3 & 0.818 & 0.892 & 0.623 \\
\hline & PE4 & 0.815 & & \\
\hline & PE5 & 0.769 & & \\
\hline \multirow[t]{5}{*}{$\mathrm{EE}$} & EE1 & 0.783 & & \\
\hline & EE2 & 0.815 & & \\
\hline & EE3 & 0.828 & 0.905 & 0.655 \\
\hline & EE4 & 0.821 & & \\
\hline & EE5 & 0.798 & & \\
\hline \multirow[t]{5}{*}{ SI } & SI1 & 0.787 & & \\
\hline & $\mathrm{SI} 2$ & 0.798 & & \\
\hline & SI3 & 0.774 & 0.874 & 0.581 \\
\hline & SI4 & 0.661 & & \\
\hline & SI5 & 0.783 & & \\
\hline \multirow[t]{5}{*}{$\mathrm{FC}$} & FC1 & 0.520 & & \\
\hline & $\mathrm{FC} 2$ & 0.717 & & \\
\hline & FC3 & 0.773 & 0.842 & 0.521 \\
\hline & FC4 & 0.845 & & \\
\hline & FC5 & 0.714 & & \\
\hline \multirow[t]{5}{*}{$\mathrm{HM}$} & HM1 & 0.723 & & \\
\hline & HM2 & 0.778 & & \\
\hline & HM3 & 0.764 & 0.870 & 0.573 \\
\hline & HM4 & 0.787 & & \\
\hline & HM5 & 0.731 & & \\
\hline \multirow[t]{5}{*}{ PV } & PV1 & 0.727 & & \\
\hline & PV2 & 0.921 & & \\
\hline & PV3 & 0.859 & 0.898 & 0.637 \\
\hline & PV4 & 0.794 & & \\
\hline & PV5 & 0.786 & & \\
\hline \multirow[t]{5}{*}{ HT } & HT1 & 0.822 & & \\
\hline & HT2 & 0.815 & & \\
\hline & HT3 & 0.830 & 0.910 & 0.670 \\
\hline & HT4 & 0.830 & & \\
\hline & HT5 & 0.794 & & \\
\hline \multirow[t]{6}{*}{ BI } & BI1 & 0.726 & & \\
\hline & $\mathrm{BI} 2$ & 0.721 & & \\
\hline & $\mathrm{BI} 3$ & 0.761 & & \\
\hline & BI4 & 0.787 & 0.878 & 0.546 \\
\hline & BI5 & 0.739 & & \\
\hline & BI6 & 0.696 & & \\
\hline
\end{tabular}

Note. AVE (average variance extracted)

Composite reliability values scrutinise reliability. The figures of composite reliability ranged from 0.842 to 0.91 , which is beyond the recommended threshold of 0.70 . This result indicated adequate reliability of the constructs (Zhou et al., 2014). Indicator reliability is assessed by looking at the item loadings. According to the Yang (2013), adequate reliability is exhibited since the loadings exceeded 0.7. However, items SI4, FC1, and BI6 exhibited item loadings below the threshold of 0.7. This implied their lower 
significance to the model. Convergent validity is assessed using the average variance extracted (AVE). The entire values of AVE were more than 0.5: ranging from 0.521 to 0.67 . This suggested satisfactory convergent validity (Arenas-Gaitan et al., 2015). Table 5 shows that all constructs' discriminant validities were achieved as the square roots of each construct's AVE exceeded the correlations between constructs (Briz-Ponce et al., 2017; Fornell \& Larcker, 1981).

Table 5

Discriminant validity statistics

\begin{tabular}{lllllllll}
\hline & BI & EE & FC & HM & HT & PE & PV & SI \\
\hline BI & 0.739 & & & & & & & \\
EE & 0.200 & 0.809 & & & & & & \\
FC & 0.135 & 0.019 & 0.722 & & & & & \\
HM & 0.383 & 0.180 & 0.206 & 0.757 & & & & \\
HT & 0.436 & 0.195 & 0.095 & 0.272 & 0.818 & & & \\
PE & 0.223 & 0.256 & 0.102 & 0.261 & 0.218 & 0.789 & & \\
PV & 0.256 & 0.084 & 0.127 & 0.192 & 0.253 & 0.094 & 0.798 & \\
SI & 0.248 & 0.153 & 0.087 & 0.277 & 0.162 & 0.160 & 0.144 & 0.762 \\
\hline
\end{tabular}

Structural model assessment

The study's structural model was reviewed for explanatory power and path significance via the bootstrapping technique (Zhou et al., 2014). The $R^{2}$ amounted to $29.9 \%$, which indicated that a significant amount of variation in BI could be explained by PEPE, EE, SI, FC, HM, PV, and HT. The $R^{2}$ value is deemed substantial when it is greater than 0.26 (Isaac, Masoud, Samad, \& Abdullah, 2016). Hence, this model was a good fit in the context of mobile learning. Figure 2 shows the path co-efficient and $\mathrm{R}^{2}$ value. Figure 3 shows the bootstrapping results of this research.

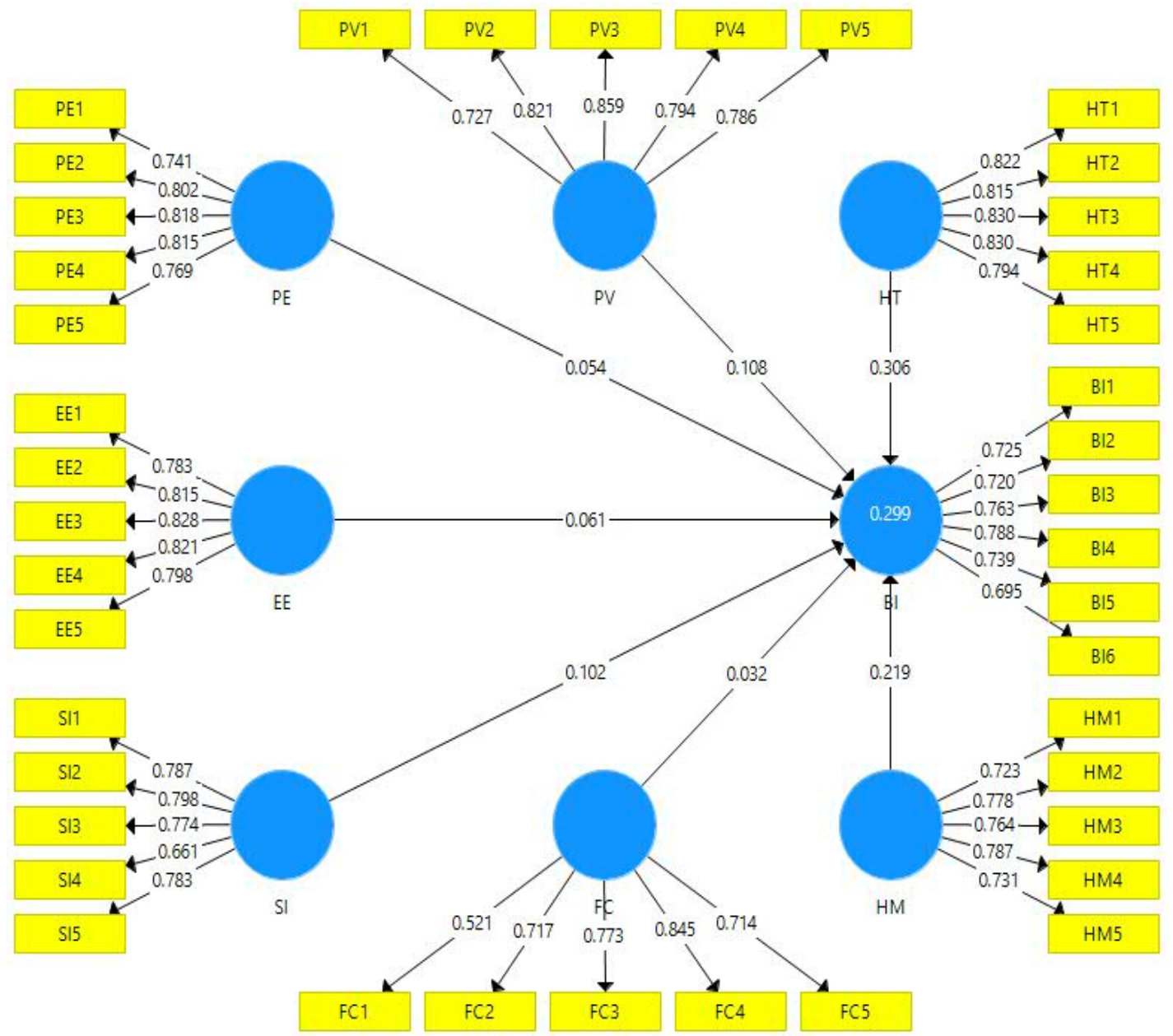

Figure 2. Path coefficients and $R^{2}$ value 


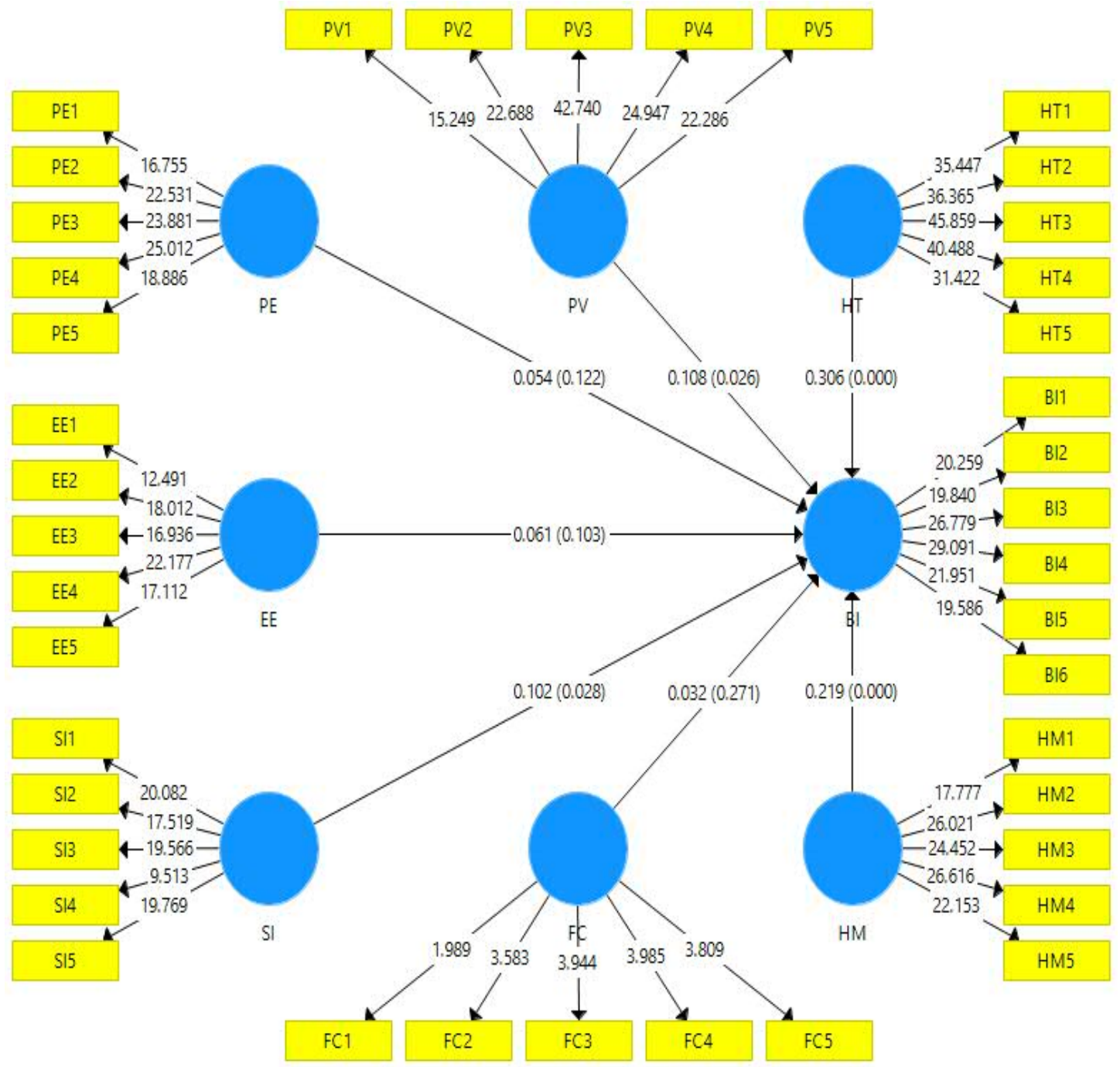

Figure 3. Bootstrapping results

BI was predicted by seven constructs with different degrees of significance. As shown in Table 6, SI, HM, PV, and HT had significant impact on accounting students' BI to use mobile learning. However, PE, EE, and FC were found to be insignificant. The most influential construct towards BI was HT ( $\beta=0.306, t=$ $4.66)$, while the second most prominent predictor was HM $(\beta=0.219, t=3.44)$. This was followed by PV and SI, which exhibited path coefficients of $0.108(t=1.942)$ and $0.102(t=1.914)$ respectively. HT, HN, $\mathrm{PV}$ and SI demonstrated positive and significant effects on the endogenous variable.

Table 6

Hypothesis, path coefficients, $t$-values and $p$-values

\begin{tabular}{lrrrrc}
\hline & Path coefficients & $t$ & $p$-values & Hypothesis & Results \\
\hline PE $\rightarrow$ BI & 0.054 & 1.165 & 0.122 & H1 & Not supported \\
EE $\rightarrow$ BI & 0.061 & 1.265 & 0.103 & H2 & Not supported \\
SI $\rightarrow$ BI & 0.102 & 1.914 & 0.028 & H3 & Supported* \\
FC $\rightarrow$ BI & 0.032 & 0.609 & 0.271 & H4 & Not supported \\
HM $\rightarrow$ BI & 0.219 & 3.440 & 0.000 & H5 & Supported** \\
PV $\rightarrow$ BI & 0.108 & 1.942 & 0.026 & H6 & Supported* \\
HT $\rightarrow$ BI & 0.306 & 4.660 & 0.000 & H7 & Supported** \\
\hline
\end{tabular}

Note. $* p \leqslant 0.05, * * p \leqslant 0.01$ 


\section{Discussion}

This study did not find evidence for the influence of PE on BI to adopt mobile learning. This was in line with the work of Cheng, Yu, Huang, Yu, and Yu (2011), Schaper and Pervan (2007), and Vanneste, Vermeulen, and Declercq (2013). It indicated that individuals were attracted to the system due to reasons apart from the system's ability to improve the learning process. This finding provided support for the findings of Letchumanan and Muniandy (2013), confirming that the evaluation of PU entails time and actual use of a system. Since mobile learning is at its embryonic stage of growth, the extent to which students' embrace of mobile learning may be relatively low (Park, 2011; Sabah, 2016).

This research illustrated that EE does not pose significant influence on BI to adopt mobile learning. The outcome upholds the findings of Kang et al. (2015) and Oliveira, Faria, and Thomas (2014), who posited that the accomplishment of an mobile learning task does not rely on the effort employed to use the system. This may be explained by the notion that students have become more accustomed to computers and mobile platforms (Rehman, Anjum, Askri, Kamran, \& Esichaikul, 2016; Üzdoğan, Basoglu, \& Ercetin, 2012). As learners are more adaptive to new technology, they prepare and train themselves to accomplish learning tasks (Rehman et al., 2016), which in turn weakens the impact of EE.

In line with the studies of Ahmad and Khalid (2017), Lakhal and Khechine (2016), and Sabah (2016), SI was found to possess positive and substantial influence on BI. This result suggests that students believe the opinions, perceptions, and attitudes of their peers, parents, and lecturers can impact them in embracing a mobile learning system. In other words, undergraduates are more inclined to engage in mobile learning when they perceive their important communal influences support them to accept mobile learning.

On the other hand, the outcome of this study postulates that accounting students' BI to implement mobile learning is not considerably affected by FCs. This result is consistent with the findings of Teo and Noyes (2012), Jambulingam (2013), and Arenas-Gaitan et al. (2015). Infrastructure support to use mobile learning becomes unnecessary because younger generation are equipped with skills to utilise new technology (Diño \& de Guzman, 2015). Furthermore, FCs effect may be captured by EE (Venkatesh et al., 2002).

HM was shown to exert a significant positive impact on the intention of mobile learning adoption. This finding is affirmed by investigations conducted by Kang et al. (2015), Herrero and San Martin (2017), and Alalwan et al. (2017). Based on the results of this study, it can be inferred that if the students find the mobile learning system's functions and features enjoyable and enticing, the probability for them to utilise the system is higher. A mobile device is assumed to provide users with great pleasure and contentment from allowing them to store data, access to real-time information, capture pictures and record videos (Sabah, 2016).

PV was found to elicit a significant impact on BI. The findings of Nair et al. (2015), Sung and Sung (2015), and $\mathrm{Xu}$ (2014) agreed with the outcome of this research, and it can be concluded that the cost and charges of mobile learning affect the intention of students in applying mobile learning system. Learners are prone to embrace the technology when it harvests greater benefits compared to the cost (Isa \& Wong, 2015). However, if the price of mobile learning does not match its value, students' intention of implementing the system will be negatively affected.

HT was reported to demonstrate a remarkable positive influence in relation to BI and served as the strongest determinant in the study. The result provides support for past studies conducted by Harsono and Suryana (2014), Escobar-Rodriguez et al. (2014), and Yeh and Tseng (2017). Students who are accustomed to the use of technology may have a positive intention in using mobile learning (Tarhini, Mohammed, \& Maqableh, 2016). In other words, increase of the usage of mobile devices among the digital generation may have caused dependence on mobile applications and prompted stronger automaticity levels in applying mobile learning system.

After performing a partial least squares-based multi-group analysis this study concluded that there was no moderating effect between GT and BI. This finding is congruent with research done by Arenas-Gaitan et al. (2015), Diño and de Guzman (2015), and Krishnapillai and Ying (2017). The results of this study confirm that the effects of SI, HM, PV, and HT are similar in pathway and size for male and female 
learners. Since the digital gap between male and female is reducing (Faqih \& Jaradat, 2015), this could be one of the reasons that technology systems have become more manageable by both genders (Diño \& de Guzman, 2015). The gender gap of technology acceptance is narrowed through technology proficiency enhancement courses and improved information and communication technology access (Lee, Park, \& Hwang, 2015). Table 7 shows the results of the moderating effects of gender.

Table 7

Moderating effects of gender

\begin{tabular}{lrrrcc}
\hline & Path coefficients & \multicolumn{1}{c}{$t$-values } & $p$-values & Hypothesis & Results \\
\hline PE x GT $\rightarrow$ BI & 0.026 & 0.282 & 0.778 & H8 & Not supported \\
EE x GT $\rightarrow$ BI & 0.003 & 0.032 & 0.974 & H9 & Not supported \\
SI x GT $\rightarrow$ BI & 0.114 & 1.143 & 0.254 & H10 & Not supported \\
FC x GT $\rightarrow$ BI & 0.025 & 0.202 & 0.840 & H11 & Not supported \\
HM x GT $\rightarrow$ BI & 0.149 & 1.234 & 0.218 & H12 & Not supported \\
PV x GT $\rightarrow$ BI & 0.069 & 0.679 & 0.497 & H13 & Not supported \\
HT x GT $\rightarrow$ BI & 0.103 & 0.818 & 0.414 & H14 & Not supported \\
\hline
\end{tabular}

\section{Contribution}

This research probed into the dynamics of technology acceptance in the domain of mobile learning, with specific emphasis on the moderating effects of gender. Differing from what was hypothesised in this study, gender did not display moderation impact on the BI. Unlike numerous preceding studies which posited that the adoption of technology depends predominantly upon the technology's performance and EE (Faqih \& Jaradat, 2014), this study found that HT is the strongest determinant. Consistent usage of mobile learning could be encouraged through implementation of rules and regulations by the educational institutions to nurture students' HTs in using mobile learning systems. Seminars, workshops, and awareness campaigns held regularly could garner interest and cultivate learners' HT to use mobile learning.

Previous research on information system adoption in organisational settings tended to assert that HM is secondary to utilitarian motivation: the idea that usefulness is more important than beauty (Yang, 2013). However, this study revealed that HM is more important than PE and EE. This result provides valuable insight for educators to formulate and design interesting interface and enjoyable contents of mobile learning system. The design of mobile learning should encompass features which can deliver greater satisfaction. In addition, mobile learning can be promoted to learners by using the exterior SI of social networks. This study also affirms that PV is a vital factor of mobile learning adoption. Students will embrace mobile learning if the perceived value justifies the cost, and marketers should ensure low charges of mobile learning while offering rich features to learners.

\section{Limitations and recommendations}

Certain limitations were revealed in the current research. First, the actual use of mobile learning was not incorporated in the proposed conceptual framework. Second, the causality among the constructs may not be readily inferred owing to the study's cross-sectional nature. Third, the investigation was based on the respondents' self-reported intention to use mobile learning, not their actual usage. Lastly, since the sampling locations were confined to public universities only, the findings could not be generalised across both public and private universities.

Apart from considering BI, future scholars are encouraged to integrate actual use of technology in the proposed model and adopt a longitudinal study to validate the cause-effect relationships. Furthermore, instead of relying on self-reported intention to use, actual usage of mobile learning is recommended to be tracked and recorded to deliver insightful information on students' mobile learning progress. Further studies are encouraged to broaden the sample size and involve an extensive range of public and private tertiary education institutions. 


\section{Conclusion}

The outcomes of the current study underlined prominent insights pertaining to accounting students' acceptance of mobile learning by expanding UTAUT2, in the Malaysian context. The study established that HT is the most significant factor, followed by HM, PV, and SI. Nevertheless, PEPE, EE, and FC are not strongly associated with BI. This finding could improve the quality of education, benefiting students from both pedagogical and instructional perspectives. Accounting educators should strive to enhance learning outcomes and enrich education by making greater moves toward integrating mobile learning into the classroom.

\section{References}

Abachi, H. R., \& Muhammad, G. (2014).The impact of mobile learning technology on students and educators. Computers in Human Behaviour, 30, 491-496.

Abu-Al-Aish, A., \& Love, S. (2013). Factors influencing students' acceptance of mobile learning: An investigation in higher education. The International Review of Research in Open and Distributed Learning, 14(5), 82-107.

Aguayo, C., Cochrane, T., \& Narayan, V. (2017). Key themes in mobile learning: Prospects for learnergenerated learning through AR and VR. Australasian Journal of Educational Technology, 33(6), $27-$ 40. https://doi.org/10.14742/ajet.3671

Ahmad, S. Z., \& Khalid, K. (2017). The adoption of M-government services from the user's perspectives: Empirical evidence from the United Arab Emirates. International Journal of information Management, 37(5), 367-379. https://doi.org/10.1016/i.ijinfomgt.2017.03.008

Ahmed, M. S. (2016). Technology acceptance of smartphones as mobile learning tools: A contextual comparative study of engineering and education colleges (Doctoral dissertation). University of Canterbury, New Zealand.

Ain, N., Kaur, K., \&Waheed, M. (2015). The influence of learning value on learning management system use: An extension of UTAUT2. Information Development, 32(5), 1-16. https://doi.org/10.1177/0266666915597546

Ajzen, I. (1985). From intentions to actions: A theory of planned behaviour. Berlin: Springer.

Alalwan, A. A., Dwivedi, Y. K., \& Rana, N. P. (2017). Factors influencing adoption of mobile banking by Jordanian bank customers: Extending UTAUT2 with trust. International Journal of Information Management, 37(3), 99-110. https://doi.org/10.1016/j.ijinfomgt.2017.01.002

Al-Hujran, O., Al-Lozi, E., \& Al-Debei, M. M. (2014). Get ready to mobile-learning: Examining factors affecting college students' BI to use mobile learning in Saudi Arabia. Jordan Journal of Business Administration, 10(1), 111-127.

Almaiah, M. A., Jalil, M. A., \& Man, M. (2016).Extending the TAM to examine the effects of quality features on mobile learning acceptance. Journal of Computers in Education, 3(4), 453-485.

Ambient Insight Comprehensive Report (2015). The worldwide market for mobile learning products and services: 2014-2019 forecast and analysis. Retrieved from

http://www.ambientinsight.com/Resources/Documents/AmbientInsight-2014-2019-Asia-MobileLearning-Market-Overview.pdf

Amirul, S. M., Mail, R., Bakar, M. A., \& Ripain, N. (2017). Information technology knowledge and skills for accounting graduates: An insight from public accounting firms. Indian Journal of Science and Technology, 10(12), 1-6. https://doi.org/10.17485/ijst/2017/v10i12/112976

Arenas-Gaitan, J., Peral-Peral, B., \& Ramon-Jeronimo, M. A. (2015). Elderly and internet banking: An application of UTAUT2. Journal of Internet Banking and Commerce, 20(1), 1-20.

Bakar, A., \& Razak, F. Z. A. (2014). The role of facilitating condition and social influence towards continuance intention to use e-learning. International Journal of Technical Research and Applications, 2(1), 12-14.

Briz-Ponce, L., Pereira, A., Carvalho, L., Juanes-Méndez, J. A., \& García-Peñalvo, F. J. (2017). Learning with mobile technologies - students' behaviour. Computers in Human Behaviour, 72, 612-620. https://doi.org/10.1016/j.chb.2016.05.027

Chang, C. T., Hajiyev, J., \& Su, C. R. (2017). Examining the students' behavioural intention to use elearning in Azerbaijan? The general extended technology acceptance model for e-learning approach. Computers \& Education, 111, 128-143. https://doi.org/10.1016/j.compedu.2017.04.010 
Chang, K. C. (2016). Effect of service scape on customer behavioural intentions: Moderating roles of service climate and employee engagement. International Journal of Hospitality Management, 53. 116-128. https://doi.org/10.1016/j.ijhm.2015.12.003

Chauhan, S., \& Jaiswal, M. (2016). Determinants of acceptance of ERP software training in business schools: Empirical investigation using UTAUT model. The International Journal of Management Education, 14(3), 248-262. https://doi.org/10.1016/j.ijme.2016.05.005

Cheng, Y. S., Yu, T. F., Huang, C. F., Yu, C., \& Yu, C. C. (2011). The comparison of three major occupations for user acceptance of information technology: Applying the UTAUT model. IBusiness, 3(2), 147-158.

Chuang, S. H., Lin, S., Chang, T. C., \& Kaewmeesri, R. (2017). Behavioural intention of using social networking site: A comparative study of Taiwanese and Thai Facebook users. International Journal of Technology and Human Interaction, 13(1), 61-81. https;//doi.org/10.4018/IJTHI.2017010104

Cory, S. N., \& Peruske, K. A. (2012). Necessary skills for accounting graduates: An exploratory study to determine what the profession wants. Proceedings of the American Society of Business and Behavioral SciencesAnnual Conference, Las Vegas, 208-218.

Davis, F. D. (1986). A technology acceptance model for empirically testing new end-user information systems: Theory and results (Doctoral dissertation). Massachusetts Institute of Technology, MA.

De Sena Abrahão, R., Moriguchi, S. N., \& Andrade, D. F. (2016). Intention of adoption of mobile payment: An analysis in the light of the unified theory of acceptance and use of technology (UTAUT). RAI-Revista de Administração e Inovação, 13(3), 221-230. https://doi.org/10.1016/j.rai.2016.06.003

Diño, M. J. S., \& de Guzman, A. B. (2015).Using partial least squares (PLS) in predicting behavioural intention for telehealth use among Filipino elderly. Educational Gerontology, 41(1), 53-68. https://doi.org/10.1080/03601277.2014.917236

El-Dalahmeh, S. M. (2017). Information technology (IT) competencies desired in new accounting graduates: A survey in Jordanian business environment. International Journal of Business and Management, 12(5), 202-208. https://doi.org/10.5539/ijbm.v12n5p202

El-Masri, M., \& Tarhini, A. (2017). Erratum to: Factors affecting the adoption of e-learning systems in Qatar and USA: Extending the unified theory of acceptance and use of technology 2 (UTAUT2). Educational Technology Research and Development, 65(3), 765-767. https://doi.org/10.1007/s11423-016-9508-8

Escobar-Rodríguez, T., Carvajal-Trujillo, E., \&Monge-Lozano, P. (2014). Factors that influence the perceived advantages and relevance of Facebook as a learning tool: An extension of the UTAUT. Australasian Journal of Educational Technology, 30(2), 136-151.

Faqih, K. M., \& Jaradat, M. I. R. M. (2015).Assessing the moderating effect of gender differences and individualism-collectivism at individual-level on the adoption of mobile commerce technology: TAM3 perspective. Journal of Retailing and Consumer Services, 22, 37-52. https://doi.org/10.1016/i.jretconser.2014.09.006

Fishbein, M., \&Ajzen, I. (1975). Belief, attitude, intention and behaviour: An introduction to theory and research. Reading, MA: Addison Wesley.

Fornell, C., \& Larcker, D. F. (1981).Evaluating structural equation models with unobservable variables and measurement error. Journal of Marketing Research, 18(1), 39-50.

Garbarino, E., \& Strahilevitz, M. (2004).Gender differences in the perceived risk of buying online and the effects of receiving a site recommendation. Journal of Business Research, 57(7), 768-775.

Gilbert, D., Lee-Kelley, L., \& Barton, M. (2003). Technophobia, gender influences and consumer decision-making for technology-related products. European Journal of Innovation Management, 6(4), 253-263.

Goh, T. T., \& Sun, S. (2014). Exploring gender differences in Islamic mobile banking acceptance. Electronic Commerce Research, 14(4), 435-458.

Harsono, L. D., \& Suryana, L. A. (2014).Factors affecting the use behaviour of social media using UTAUT 2 model. Proceedings of the First Asia-Pasific Conference on Global Business, Economics, Finance and Social Sciences, Singapore, 1-14.

Herrero, Á., \& San Martín, H. (2017). Explaining the adoption of social networks sites for sharing usergenerated content: A revision of the UTAUT2. Computers in Human Behaviour, 71, 209-217. https://doi.org/10.1016/j.chb.2017.02.007

Hinkin, T. R. (1995). A review of scale development practices in the study of organisations. Journal of Management, 21(1), 967-988. 
Hussin, S., Manap, M. R., Amir, A., \& Krish, P. (2012). Mobile learning readiness among Malaysia students at higher education institutes. Asian Social Science, 8(12), 276-283.

Indrawati, \& Marhaeni, G. A. M. M. (2015). Predicting instant messenger application adopting using a Unified Theory of Acceptance and Use of Technology 2. Proceedings of the 5th International Conference on Computing and Informatics, Istanbul, 11-13.

International Telecommunication Unit (2015). ICT facts \& figures: The world in 2016. Retrieved from http://www.itu.int/en/ITU-D/Statistics/Pages/stat/default.aspx

Isa, S. M., \& Wong, K. Y. (2015). Age differences in behavioural intention to use internet marketing: A comparative study between Malaysian and Taiwanese. International Journal of Business and Society, 16(3), 386-396.

Isaac, O., Masoud, Y., Samad, S., \& Abdullah, Z. (2016). The mediating effect of strategic implementation between strategy formulation and organizational performance within government institutions in Yemen. Research Journal of Applied Sciences, 11(10), 1002-1013.

Ismail, I., Gunasegaran, T., \& Azizan, S. N. (2016). Mobile learning in Malaysian universities: Are students ready? International Journal of Interactive Mobile Technologies, 10(3), 17-23. https://doi.org/10.3991/ijim.v10i3.5316

Jackman, G. (2014). Investigating the factors influencing students' acceptance of mobile learning: The cave hill campus experience. Caribbean Educational Research Journal, 2(2), 14-32.

Jambulingam, M. (2013).Behavioural intention to adopt mobile technology among tertiary students. World Applied Sciences Journal, 22(9), 1262-1271.

Kang, M., Liew, B. Y. T., Lim, H., Jang, J., \& Lee S. (2015) Investigating the determinants of mobile learning acceptance in Korea using UTAUT2. In G. Chen, V. Kumar, Kinshuk, R. Huang, \& S. Kong (Eds), Emerging issues in smart learning. Lecture notes in educational technology (pp. 209-216). Springer, Berlin, Heidelberg.

Kengwe, J., \& Bhargava, M. (2014).Mobile learning and integration of mobile technologies in education. Education and Information Technologies, 19(4), 737-746.

Kimball, J. (2015). Motivations of students in the open-ended use of mobile computing in lecture-based classrooms (Doctoral dissertation). Nova Southeastern University, Florida. Retrieved from https://nsuworks.nova.edu/gscis_etd/366

Kline, P. (2015). A handbook of test construction (psychology revivals): Introduction to psychometric design. London: Routledge.

Krishnapillai, G., \& Ying, K. S. (2017). The influence of E-WOM on travel intention among foreign students in Malaysia: Does gender really matter? International Review of Management and Marketing, 7(1), 475-483. http://www.econjournals.com/index.php/irmm/article/download/3582/pdf

Kurfali, M., Arifoğlu, A., Tokdemir, G., \& Paçin, Y. (2017). Adoption of e-government services in Turkey. Computers in Human Behaviour, 66, 168-178. https://doi.org/10.1016/j.chb.2016.09.04

Lakhal, S., \& Khechine, H. (2016). Student intention to use desktop web-conferencing according to course delivery modes in higher education. The International Journal of Management Education, 14(2), 146-160. https://doi.org/10.1016/j.ijme.2016.04.001

Lawrence, B. (2016). Ipad acceptance by English learners in Saudi Arabia. English Language Teaching, $9(12), 34-46$.

Lee, H., Park, N., \& Hwang, Y. (2015). A new dimension of the digital divide: Exploring the relationship between broadband connection, smartphone use and communication competence. Telematics and Informatics, 32(1), 45-56.

Leong, L.Y., Ooi, K. B., Chong, A. Y. L., \& Lin, B. (2013). Modeling the stimulators of the behavioural intention to use mobile entertainment: does gender really matter? Computers in Human Behaviour, 29(5), 2109-2121.

Letchumanan, M., \& Muniandy, B. (2013). Migrating to e-book: A study on perceived usefulness and ease of use. Library Hi Tech News, 30(7), 10-16.

Lewis, C. C., Fretwell, C. E., Ryan, J., \& Parham, J. B. (2013). Faculty use of established and emerging technologies in higher education: A unified theory of acceptance and use of technology perspective. International Journal of Higher Education, 2(2), 22-34.

Liu, D., \& Guo, X. (2017).Exploring gender differences in acceptance of mobile computing devices among college students. Information Systems and e-Business Management, 15(1), 197-223. https://doi.org/10.1007/s10257-016-0315-X

Magsamen-Conrad, K., Upadhyaya, S., Joa, C. Y., \& Dowd, J. (2015). Bridging the divide: Using UTAUT to predict multigenerational tablet adoption practices. Computers in Human Behaviour, 50, 186-196. 
Morosan, C., \& DeFranco, A. (2016). It's about time: Revisiting UTAUT2 to examine consumers' intentions to use NFC mobile payments in hotels. International Journal of Hospitality Management, 53, 17-29.

Mtebe, J. S., Mbwilo, B., \& Kissaka, M. M. (2016). Factors influencing teachers' use of multimedia enhanced content in secondary schools in Tanzania. International Review of Research in Open and Distributed Learning, 17(2), 65-84.

Nair, P. K., Ali, F., \& Leong, L. C. (2015). Factors affecting acceptance \& use of ReWIND: Validating the extended unified theory of acceptance and use of technology. Interactive Technology and Smart Education, 12(3), 183-201.

Nassuora, A. B. (2012). Students' acceptance of mobile learning for higher education in Saudi Arabia. American Academic \& Scholarly Research Journal, 4(2).

Oliveira, T., Faria, M., \& Thomas, M. A. (2014).Extending the understanding of mobile banking adoption: When UTAUT meets TTF and ITM. International Journal of information Management, 34(1), 689703.

Ooi, K., \& Tan, G. (2016). Mobile technology acceptance model: An investigation using mobile users to explore smartphone credit card. Expert Systems with Applications, 59, 33-46.

Park, Y. (2011). A pedagogical framework for mobile learning: Categorizing educational applications of mobile technologies into four types. International Review of Research in Open and Distributed Learning, 12(2), 78-102.

Pollara, P., \& Kee, B. K. (2011). Student perceptions of mobile learning: A review of current research. Proceedings of Society for Information Technology \& Teacher Education International Conference, Chesapeake, VA, 1643-1650.

Rahman, A. L., Jamaludin, A., \& Mahmud, Z. (2011).Considering race, mode of study, university and academic structure differences on behavioural intention to use information systems. Proceedings of the 2011 IEEE Colloquium on Humanities, Science and Engineering, Penang, 117-120.

Rehman, M., Anjum, M., Askri, F., Kamran, M. A., \& Esichaikul, V. (2016). Mobile learning adoption framework: An empirical investigation from learners' perspective. Journal of Quality and Technology Management, 12(1), 1-43.

Rogers, E. M. (1995). Diffusion of innovations. New York, NY: Free Press.

Rosli, N. F. (2015). Gender managerial workforce and partial least squares on small and medium enterprises (SMEs) performances in Selangor, Malaysia. The International Journal of Business \& Management, 3(3), 185-192.

Sabah, N. M. (2016). Exploring students' awareness and perceptions: Influencing factors and individual differences driving mobile learning adoption. Computers in Human Behaviour, 65, 522-533.

Schaper, L. K., \&Pervan, G. P. (2007). ICT and OTs: A model of information and communication technology acceptance and utilisation by occupational therapists. International Journal of Medical Informatics, $76(\mathrm{~S} 1), 212-221$.

Shen, C. W., Ho, J. T., Kuo, T. C., \& Luong, T. H. (2017).Behavioural intention of using virtual reality in learning. Proceedings of the 26th International Conference on World Wide Web Companion, Geneva, 129-137.

Sithole, S. (2015). Quality in accounting graduates: Employer expectations of the graduate skills in the bachelor of accounting degree. European Scientific Journal, 11(22), 165-180.

Staples, J., Collum, T., \& McFry, K. (2016). Mobile devices in the accounting classroom [Blog post]. Retrieved from https://blog.cengage.com/wp-content/uploads/2016/05/Spring-2016 Staples-CollumMcFry Mobile-Devices-in-the-Accounting-Classroom 5.pdf

Sung, H., \& Sung, J. (2015). Research on intention to adopt smart wear: Based on extended UTAUT model. Fashion business, 19(2), 69-84.

Tan, G. W. H., Lee, V. H., Lin, B., \& Ooi, K. B. (2017). Mobile applications in tourism: The future of the tourism industry? Industrial Management \& Data Systems, 117(3), 560-581. https://doi.org/10.1108/IMDS-12-2015-0490

Tan, G. W. H., Ooi, K. B., Chong, S. C., \& Hew, T. S. (2014). NFC mobile credit card: The next frontier of mobile payment? Telematics and Informatics, 31(2), 292-307.

Tandon, U., Kiran, R., \& Sah, A. N. (2016). Understanding online shopping adoption in India: Unified theory of acceptance and use of technology 2 (UTAUT2) with perceived risk application. Service Science, 8(4), 420-437.

Tarhini, A., Mohammed, A. B., \& Maqableh, M. (2016). Modeling factors affecting student's usage behaviour of e-learning systems in Lebanon. International Journal of Business and Management, 11(2), 299-312. 
Teo, T., \& Noyes, J. (2012).Explaining the intention to use technology among pre-service teachers: A multi-group analysis of the unified theory of acceptance and use of technology. Interactive Learning Environments, 2(1), 51-66.

Üzdoğan, K. M., Başoğlu, N., \& Erçetin, G. (2012). Exploring major determinants of mobile learning adoption. Proceedings of Technology Management for Emerging Technologies, Vancouver, 14151423.

Vanneste, D., Vermeulen, B., \& Declercq, A. (2013). Healthcare professionals' acceptance of BelRAI, a web-based system enabling person-centred recording and data sharing across care settings with interRAI instruments: A UTAUT analysis. BMC Medical Informatics \& Decision Making, 13(129), 1 14.

Venkatesh, V., Morris, M. G., Davis, G. B., \& Davis, F. D. (2003). User acceptance of information technology: Towards a unified view. MIS Quarterly, 27(3), 425-478.

Venkatesh, V., Thong, J. Y., \& Xu, X. (2012). Consumer acceptance and use of information technology: Extending the unified theory of acceptance and use of technology. MIS quarterly, 36(1), 157-178.

Wang, Y. S., Wu, M. C., \& Wang, H. Y. (2009).Investigating the determinants and age and gender differences in the acceptance of mobile learning. British Journal of Educational Technology, 40(1), 92-118.

Watty, K., McKay, J., \& Ngo, L. (2016).Innovators or inhibitors? Accounting faculty resistance to new educational technologies in higher education. Journal of Accounting Education, 36, 1-15.

Wong, C. H., Tan, G. W., Loke, S. P., \& Ooi, K. B. (2014). Mobile TV: a new form of entertainment? Industrial Management \& Data Systems, 114(7), 1050-1067.

$\mathrm{Xu}, \mathrm{X}$. (2014). Understanding users' continued use of online games: An application of UTAUT2 in social network games. Sixth International Conference on Advances in Multimedia, Nice, 58-65.

Yang, S. (2013). Understanding undergraduate students' adoption of mobile learning model: A perspective of the extended UTAUT2. Journal of Convergence Information Technology, 8(10), 969979.

Yeh, M. L., \& Tseng, Y. L. (2017). The college students' behaviour intention of using mobile payments in Taiwan: An exploratory research. Proceedings of International Academy of Science, Technology, Engineering and Management International Conference, Singapore, 2-6.

Yurdagül, C., \& Öz, S. (2018). Attitude towards mobile learning in English language education. Education Sciences, 8(142), 1-14. https://doi.org/10.3390/educsci8030142

Zhang, X., Guo, X., Lai, K., Guo, F., \& Li, C. (2013). Understanding gender differences in m-health adoption: A modified theory of reasoned action model. Telemedicine and e-Health, 20(1), 39-46.

Zhou, Z., Jin, X. L., \& Fang, Y. (2014). Moderating role of gender in the relationships between perceived benefits and satisfaction in social virtual world continuance. Decision support systems, 65, 69-79.

Zhu, W. W., Wei, J. C., \& Zhao, D. T. (2016). Anti-nuclear behavioural intentions: The role of perceived knowledge, information processing, and risk perception. Energy Policy, 88, 168-177.

Corresponding author: Krishna Moorthy, krishnam@utar.edu.my

Please cite as: Moorthy, K., Tsen, T. Y., Loh, C. T., \& Vikniswari, V. K. (2019). Habit and hedonic motivation are the strongest influences in mobile learning behaviours among higher education students in Malaysia. Australasian Journal of Educational Technology, 35(4), 174-191.

https://doi.org/10.14742/ajet.4432 